\title{
Analytical Performances of Sentinel and Vitros Direct LDL-C Assay Methods, and Classification of Patients with Hyperlipidemia
}

\section{Sentinel ve Vitros Direkt LDL-C Ölçüm Yöntemlerinin Analitik Performansları ve Hiperlipidemi Sınıflaması}

\author{
Sacide Atalay', Ralfi Singer ${ }^{2}$, Hüseyin Kayadibi ${ }^{3}$, Mehmet Murat Yekrek', Saadet Kurcenli \\ ${ }^{1}$ Haydarpasa Numune Teaching and Research Hospital, Department of Clinical Biochemistry, İstanbul, Turkey, ${ }^{2}$ Zeynep Kamil Women \\ and Obstetrical Hospital, Department of Clinical Biochemistry, İstanbul, Turkey, ${ }^{3}$ Iskenderun Military Hospital, Department of Clinical \\ Biochemistry, Iskenderun, Turkey
}

\begin{abstract}
OBJECTIVE: A simple and accurate method is necessary to measure the $L D L-C$ and $s d L D L-C$ in serum. We aimed to evaluate the analytical performances of Sentinel and Vitros direct $L D L-C$ (dLDL-C) assay methods, to compare $L D L-C$ values of these direct methods with each other and with those values calculated by Friedewald formula, and to determine which lipid parameters could be more proper for classification of patients with hyperlipidemia.
\end{abstract}

METHODS: Analytical performances of direct methods were evaluated in 60 serum samples. LDL-C was determined in different 122 sera via two different direct methods and Friedewald formula. Sentinel sdLDL-C, Vitros sdLDL-C and other evaluated lipid parameters were estimated in additional 118 serum samples.

RESULTS: Mean LDL-C concentrations for Sentinel dLDL-C, Vitros dLDL-C and Friedewald formula were $152 \pm 44 \mathrm{mg} / \mathrm{dL}$, $146 \pm 45 \mathrm{mg} / \mathrm{dL}, 141 \pm 41 \mathrm{mg} / \mathrm{dL}$, respectively $(p<0.001)$. Significant strong correlations were observed between Friedewald $L D L-C$ and both Sentinel and Vitros dLDL-C ( $r=0.934, r=0.936$, respectively). Although within-run imprecisions for direct methods were lower than $1.42 \%$, total imprecisions for Sentinel and Vitros dLDL-C were lower than $1.73 \%$ and $4.8 \%$, respectively. Sentinel and Vitros dLDL-C assay methods had $11 \%$ and $17.5 \%$ systematic error, respectively. While the lowest Friedewald $L D L-C$ concentrations were observed in hypertriglyceridemic group, the lowest $s d L D L-C$ values were obtained in normolipidemic group, although hyperlipidemia groups were based on Friedewald LDL-C.

CONCLUSION: Vitros $d L D L-C$ did not seem to be able to meet the performance criterion of NCEP ATP III for LDL-C, because its total imprecision was higher than $4 \%$. Direct assay methods significantly overestimated $L D L-C$ values compared with Friedewald formula. Preference of the Sentinel direct $L D L-C$ or SdLDL-C may be more useful for evaluation of patients with hyperlipidemia.

Key words: Friedewald formula, hyperlipidemia, $L D L-C$, sdLDL-C, sentinel, vitros

Hüseyin Kayadibi, İskenderun Asker Hastanesi Bastabipliüi, Hatay, Türkiye, Tel.03266189949Email.mdkayadibi@yahoo.com

Gelis Taribi: 11.05.2011 • Kabul Taribi: 11.05.2011

\section{ÖZET}

AMAÇ: Serumda LDL-C ve sdLDL-C ölçümü için basit ve doğru bir metot gereklidir. Sentinel ve Vitros direkt LDL-C ölçüm metodIarının analitik performanslarını değerlendirmeyi, bu iki direkt ölçüm metodunun $L D L-C$ değerlerini birbirleriyle ve Friedewald formülü ile hesaplanan LDL-C değerleri ile karșılaștırmayı ve hiperlipidemili hastaların sınıflandırılmasında hangi lipit parametresinin daha uygun olacağını belirlemeyi amaçladık.

YÖNTEMLER: Direkt metotların analitik performansları 60 serum örneğinde değerlendirildi. İki farklı direkt LDL-C ölçüm metodu ve Friedewald formülü ile farklı 122 serum örneğinde $L D L-C$ hesaplandı. Bunların dıșındaki 118 serum örneğinde Sentinel sdLDL-C, Vitros sdLDL-C ve diğer değerlendirilen lipit parametreleri ölçüldü.

BULGULAR: Sentinel direkt LDL-C, Vitros direkt $L D L-C$ ve Friedewald formülü ile hesaplanan ortalama $L D L-C$ konsantrasyonları sırasıyla $152 \pm 44 \mathrm{mg} / \mathrm{dL}, 146 \pm 45 \mathrm{mg} / \mathrm{dL}$ ve $141 \pm 41 \mathrm{mg} /$ $d L$ 'ydi, $(p<0,001)$. Friedewald $L D L-C$ ile Sentinel $d L D L-C$ ve Vitros dLDL-C arasında oldukça yüksek korelasyonlar gözlendi (sırasıyla, $r=0,934$ ve $r=0,936$ ). Direkt metodların çalıșma içi tekrarlanabilirlikleri $<\% 1,42$ iken, toplam tekrarlanabilirlikleri Sentinel dLDL-C için <\%1,73, Vitros dLDL-C için <\%4,8 idi. Sentinel ve Vitros dLDL-C ölçüm metotlarının sistematik hataları sırasıyla $\% 11$ ve \%17,5 idi. Hiperlipidemi grupları Friedewald LDL-C baz alınarak olușturulmasına rağmen, en düșük Friedewald LDL-C hipertrigliseridemik grupta, en düșük $s d L D L-C$ ise normolipidemik grupta gözlendi.

SONUÇ: Vitros dLDL-C için toplam tekrarlanabilirlik $>\% 4$ olduğu için bu metodun NCEP ATP III performans kriterlerini karșılayamadığı söylenebilir. Friedewald formülü ile hesaplanan $L D L-C$ değerleri ile karșılaștırılığında direk ölçüm metodlarındaki LDL-C değerleri anlamı șekilde yüksekti. Hiperlipidemi hastalarının değerlendirilmesinde Sentinel direkt $L D L-C$ ya da sdLDL-C'ün tercih edilmesi daha faydalı olabilir.

Anahtar kelimeler: Friedewald formülü, hiperlipidemi, $L D L-C$, sdLDL-C, sentinel, vitros 


\section{Introduction}

Epidemiological and clinical studies have well documented that elevated serum level of low-density lipoprotein cholesterol (LDL-C), a modifiable risk for coronary heart disease, certainly increases the risk for coronary artery disease (CAD) ${ }^{1,2}$. Therefore, LDL-C has been the primary target in the guidelines for prevention of $\mathrm{CAD}^{3}$, and its routine measurement has also been recommended in the evaluation and management of hypercholesterolemia.

Although high levels of LDL-C is a strong risk factor for CAD, more than $50 \%$ of all CAD events occur in individuals with normal or even low levels of LDL-C ${ }^{4}$. This may be explained by the fact that there are sub fractions of LDL particles that carry in their atherogenic potential. Recent evidences ${ }^{4-10}$ suggest that small, dense LDL particles (sdLDL) are more atherogenic than large, buoyant LDL ones.

In routine clinical practice, there is no simple method of accurate measurement of the LDL-C and sdLDL$\mathrm{C}$ in serum. Although ultracentrifugation is the method of choice, it is impossible to use it routinely, because it is an expensive instrument and as well as it requires special instrumentation and experienced personnel $^{11,12}$. Therefore, in most of the clinical laboratories the LDL-C concentrations are estimated by means of the Friedewald formula. Although this formula has strong correlation with $\beta$-quantitative assay, it cannot be applied to the samples with chylomicrons, containing more than $400 \mathrm{mg} / \mathrm{dL}$ of triglyceride (TG) concentrations and to the patients with type III hyperlipoproteinemia. Friedewald formula should also be used carefully in patients with diabetes mellitus, obesity, chronic renal and liver diseases, and even in patients with TG concentration of $200-400 \mathrm{mg} /$ $\mathrm{dL}^{13-15}$. In addition, because of the variations of the used methods, the accuracy levels may not be applicable to all third generation direct LDL-C methods available. Although these assays are free from the limitations of the Friedewald formula, the third report of the National Cholesterol Education Program (NCEP) Adult Treatment Panel (ATP) III do not specify any particular method to determine serum LDL-C concentration ${ }^{3}$.

In this study, we aimed (a) to evaluate the analytical performances of Sentinel dLDL-C and Vitros dLDL-C assay methods, (b) to compare these direct methods with each other and with Friedewald formula, (c) to determine the proper biochemical marker to classify the hyperlipidemia.

\section{Methods}

We have evaluated the analytical performances of Sentinel and Vitros direct LDL-C methods by means of imprecision and linearity studies. sdLDL-C and some of the lipid parameters were evaluated to show the probable misclassification of hyperlipidemia as a result of high TG level.

\section{Serum Pool and Imprecision Study}

Serum pools with different LDL-C concentrations and without hemolysis were prepared from sixty sera submitted to the Clinical Biochemistry Laboratory for the measurement of lipid profile to evaluate the imprecision of direct LDL-C assay methods. These serum pools were divided into two (low and high) and three (low, moderate and high) levels for Sentinel dLDL-C and Vitros dLDL-C reagents, respectively. All the serum pools were stored at $-20^{\circ} \mathrm{C}$ until the assay time.

NCCLS EP5-A2 protocol $^{16}$ was performed for the imprecision study. To evaluate the within-run imprecision, ten replicates of each assay were performed in the morning and in the afternoon using different concentrations of serum pool. Each serum pool was used twice in the morning and in the afternoon during twenty consecutive days to evaluate the between day imprecision. There was at least three-hour interval between morning and afternoon measurements. The mean of the two measurements was used for the statistical analyses. Two levels of control serum were used at each study for the quality control. Levey-Jennings figures were drawn with the control results, and results out of the quality control were excluded.

\section{Linearity Study}

$148 \mathrm{mg} / \mathrm{dL}$ and $152 \mathrm{mg} / \mathrm{dL}$ of serum samples were used for Sentinel dLDL-C and Vitros dLDL-C, respectively. Serum samples were diluted by the isotonic as $3 / 4,2 / 4,1 / 4,1 / 5$ and $1 / 10$ for the linearity study of both direct LDL-C methods according to the NCCLS EP 06-A protocol ${ }^{17}$. Each of the diluted samples was measured twice and the mean concentration was calculated for the statistical analysis. Difference from the expected value was determined for each of the diluted serum samples. 


\section{Biochemical Markers}

To compare the results of direct LDL-C assay methods with each other and with those values calculated by the Friedewald formula, 122 serum samples were used. Moreover, additional 118 serum samples were chosen from the laboratory to compare the concentrations of Sentinel sdLDL-C, Vitros sdLDL-C, Friedewald LDL-C, total cholesterol (TC), HDL-C and TG among hyperlipidemia groups. Serum dLDLC levels were estimated by the Sentinel dLDL-C and Vitros dLDL-C reagent systems using the autoanalysers [(Aeroset, Abbott, USA) and (Vitros 5.1, Johnson \& Johnson, USA), respectively]. Measurements of TC, high-density lipoprotein cholesterol (HDL-C) and TG were performed on the same day with standard methods using the autoanalyser (Aeroset, Abbott, USA). LDL-C was calculated with the Friedewald formula according to the following formulation; LDL-C $(\mathrm{mg} / \mathrm{dL})=\mathrm{TC}(\mathrm{mg} / \mathrm{dL})-[\mathrm{HDL}-\mathrm{C}(\mathrm{mg} / \mathrm{dL})+\mathrm{TG}(\mathrm{mg} /$ $\mathrm{dL}) / 5]$.

sdLDL-C was measured by using the method of Hirano et $\mathrm{al}^{7}$. In this method, combination of 150 $\mathrm{U} / \mathrm{mL}$ of heparin sodium salt (Sigma H-3393) and $90 \mathrm{mmol} / \mathrm{L}$ of $\mathrm{MgCl}_{2}$ (Riedel 31413) reagent was used to precipitate the lipoproteins consist of apolipoprotein B. $0.2 \mathrm{ml}$ of precipitation reagent was added to the $0.2 \mathrm{ml}$ of serum. Each sample was mixed by vortex for 15 seconds and incubated for 10 minutes (min) at $37^{\circ} \mathrm{C}$. Then samples were left on ice bath for $15 \mathrm{~min}$ and the clear supernatant was obtained by centrifugating at $10500 \mathrm{~g}$ for $15 \mathrm{~min}$. The supernatant was used in Sentinel sdLDL-C and Vitros sdLDL-C measurements.

\section{Statistical Analysis}

All statistical analyses were performed by using the SPSS 11 (SPSS Inc., Chicago, IL., USA) software for Windows. While parametric analyses were used for the Gaussian distributed variables, non-parametric analyses were used for the non-Gaussian distributed variables. Comparisons among LDL-C concentrations determined by three different methods and among four hyperlipidemia groups were undertaken by using the repeated measures analysis of variance and Kruskal-Wallis variance analysis, respectively. If the differences were significant, pair-wise comparisons would be based on the $t$-test for dependent groups and Mann-Whitney $U$ test with adjusting for Bonferroni correction, respectively. Spearman

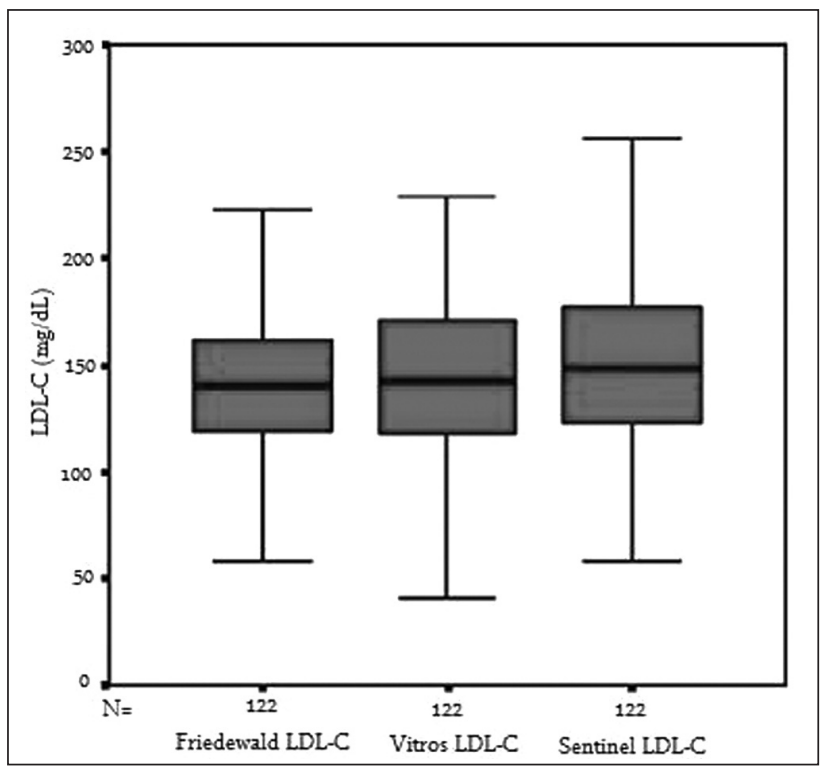

Figure 1. $L D L-C$ concentrations based on different $L D L-C$ assay methods.

correlation analysis was used to show the correlations between biochemical variables. All of the reported $p$ values were two tailed, and those less than 0.05 were considered to be statistically significant.

\section{Results}

Mean LDL-C values for Friedewald formula, Vitros dLDL-C and Sentinel dLDL-C were 141 $441 \mathrm{mg} / \mathrm{dL}$, $146 \pm 45 \mathrm{mg} / \mathrm{dL}$ and $152 \pm 44 \mathrm{mg} / \mathrm{dL}$, respectively, $(\mathrm{p}<0.001)$ (Fig. 1). P values for all pair-wise groups, Friedewald LDL-C-Sentinel dLDL-C, Sentinel dLDL-C-Vitros dLDL-C, Friedewald LDL-CVitros dLDL-C, were significant, $\mathrm{p}<0.001, \mathrm{p}<0.001$, $\mathrm{p}=0.02$, respectively. Strong correlations were observed for Friedewald LDL-C-Sentinel dLDL-C, Friedewald LDL-C-Vitros dLDL-C and Sentinel dLDL-C-Vitros dLDL-C pair wise groups ( $\mathrm{r}=0.934$, $r=0.936, r=0.925$, respectively).

Within-run imprecisions for both of the direct methods were lower than $1.42 \%$. While total coefficient of variations (CV) for Sentinel dLDL-C at low and high serum pools were $1.73 \%$ and $1.30 \%$, respectively, for Vitros dLDL-C at low, moderate and high serum pools were $3.69 \%, 4.80 \%$ and $4.10 \%$, respectively (Table 1). Although total coefficient of variation values for Sentinel dLDL-C were lower than $4 \%$, as proposed by the NCEP, the CV values were higher than $4 \%$ in moderate and high serum pools for Vitros dLDL-C. 
Sentinel dLDL-C and Vitros dLDL-C had a negative deviation of $3.5 \mathrm{mg} / \mathrm{dL}$ and $4.3 \mathrm{mg} / \mathrm{dL}$ according to the expected value, respectively. These results are equal to the $11 \%$ of systematic error for Sentinel dLDL-C assay method and are equal to the $17.5 \%$ of systematic error for Vitros dLDL-C assay method.

Table 2 shows the biochemical variables determined by the 118 sera. The lowest Friedewald LDL-C concentrations were observed in hypertriglyceridemic group which was classified according to the Friedewald LDL-C. Mean Sentinel sdLDL-C concentrations for normolipidemics, hypercholesterolemics, hypertriglyceridemics and hyperlipidemics are shown in Fig. 2.

\section{Discussion}

Vitros direct LDL-C was not able to meet the performance criterion of NCEP for LDL-C, because its total imprecision was more than $4 \%$. Mean LDL-C values obtained by direct methods were significantly higher than those calculated by the Friedewald formula. The latter may not be suitable for hypertriglyceridemia classification. Preference of Sentinel direct LDL-C or sdLDL-C may be more helpful to evaluate the patients with hyperlipidemia.

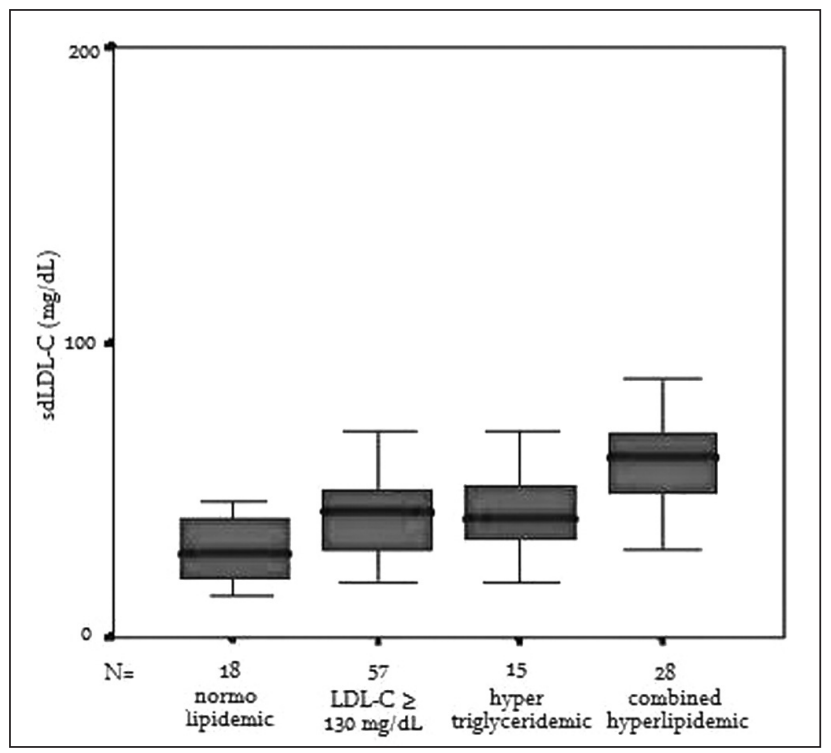

Figure 2. sdLDL-C values of normolipidemic ( $L D L-C<130 \mathrm{mg} / \mathrm{dL}, T G<150 \mathrm{mg}$ / $d L)$, hypercholesterolemic (LDL-C $\geq 130 \mathrm{mg} / \mathrm{dL}, T G<150 \mathrm{mg} / \mathrm{dL}$ ), hypertriglyceridemic ( $L D L-C<130 \mathrm{mg} / \mathrm{dL}, T G \geq 150 \mathrm{mg} / \mathrm{dL}$ ) and hyperlipidemic (LDL-C $\geq 130 \mathrm{mg} / \mathrm{dL}, \mathrm{TG} \geq 150 \mathrm{mg} / \mathrm{dL}$ ) groups.

Current primary goal for the analytical performance of the LDL-C measurement is to keep the total error ratio within $12 \%$ of the true value. The total error, combining the contributions of imprecision and

Table 1. Within-run and total imprecision for Sentinel dLDL-C and Vitros $d L D L-C$

\begin{tabular}{|c|c|c|c|c|c|c|}
\hline \multirow[t]{2}{*}{ Method } & & \multicolumn{2}{|c|}{ Sentinel dLDL-C } & \multicolumn{3}{|c|}{ Vitros dLDL-C } \\
\hline & & Low & High & Low & Moderate & High \\
\hline LDL-C (mg/dl) & & 130 & 163 & 119 & 175 & 216 \\
\hline \multirow[t]{2}{*}{ Within-run } & SD & 1.85 & 1.72 & 1.27 & 1.32 & 1.50 \\
\hline & CV\% & 1.42 & 1.05 & 1.06 & 0.76 & 0.69 \\
\hline \multirow[t]{2}{*}{ Total } & SD & 2.30 & 2.12 & 4.40 & 8.40 & 8.84 \\
\hline & CV\% & 1.73 & 1.30 & 3.69 & 4.80 & 4.10 \\
\hline
\end{tabular}

Table 2. Lipid parameters for NCEP hyperlipidemia groups

\begin{tabular}{|c|c|c|c|c|c|}
\hline Lipids (mg/dL) & Group 1 ( $n=18)$ & Group $2(\mathrm{n}=57)$ & Group $3(n=15)$ & Group $4(n=28)$ & $P$ \\
\hline Total Cholesterol & $163 \pm 32$ & $232 \pm 36$ & $185 \pm 33$ & $251 \pm 31$ & $<0.001$ \\
\hline HDL-C & $48 \pm 12$ & $53 \pm 13$ & $42 \pm 10$ & $49 \pm 8$ & 0.007 \\
\hline LDL-C, Friedewald & $98 \pm 24$ & $160 \pm 31$ & $94 \pm 25$ & $163 \pm 26$ & $<0.001$ \\
\hline Triglyceride & $85 \pm 26$ & $96 \pm 28$ & $244 \pm 62$ & $198 \pm 36$ & $<0.001$ \\
\hline Apolipoprotein B & $73 \pm 15$ & $106 \pm 21$ & $89 \pm 17$ & $120 \pm 16$ & $<0.001$ \\
\hline sdLDL-C, Sentinel & $30.6 \pm 14.6$ & $43.7 \pm 23.5$ & $41.5 \pm 15.3$ & $62.8 \pm 20.5$ & $<0.001$ \\
\hline sdLDL-C, Vitros & $24.8 \pm 16.9$ & $39.2 \pm 25.9$ & $35.2 \pm 15.8$ & $60.8 \pm 22.8$ & $<0.001$ \\
\hline
\end{tabular}

Group 1: Normolipidemic : (LDL-C <130 mg/dL, TG <150 mg/dL); Group 2: Hypercholesterolemic: (LDL-C $\geq 130 \mathrm{mg} / \mathrm{dL}, \mathrm{TG}<150 \mathrm{mg} / \mathrm{dL})$; Group 3: Hypertriglyceridemic (LDL-C <130 mg/dL,TG $\geq 150 \mathrm{mg} / \mathrm{dL})$; Group 4: Hyperlipidemic: (LDL-C $\geq 130 \mathrm{mg} / \mathrm{dL}, \mathrm{TG} \geq 150 \mathrm{mg} / \mathrm{dL}$ ) 
inaccuracy or bias (systematic error), represents the maximum tolerable error level in the measurement of a single specimen up to $95 \%$ tolerance limits. Friedewald formula has the disadvantage of exceeding medically allowable error $(12 \%)$ recommended by the NCEP since Friedewald LDL-C is calculated after the measurement of TC, HDL-C and TG. Therefore, NCEP Study Group recommends the improvement of direct LDL-C assay methods. Potential advantages of dLDL-C are believed to be a better imprecision of the assay owing to the single measurement and a relative lack of the presence of hypertriglyceridemia or a nonfasting sample ${ }^{18-20}$.

Highly significant positive correlation coefficients have been observed between direct LDL-C assay methods and Friedewald formula, however in some studies inconsistent results were obtained due to the interference of high TG level. For example Cordova et al. have reported that Friedewald formula had a positive bias when TC was higher than $201 \mathrm{mg} / \mathrm{dL}$ and lower than $150 \mathrm{mg} / \mathrm{dL}^{21}$. On the other hand, direct method had a positive bias when TG level was more than $300 \mathrm{mg} / \mathrm{dL}$. In our study, we observed highly significant positive correlation coefficients between Friedewald LDL-C and the two direct methods. However, we have observed higher Friedewald LDL-C concentrations in normolipidemic group in comparison to hypertriglyceridemic group. High TG levels caused this inconsistency, however the hyperlipidemic group had higher TG and Friedewald LDL-C values in comparison to the normolipidemic group due to the elevated total cholesterol concentrations.

Eight survey samples of the College of American Pathologists Comprehensive Chemistry Survey analyzed in more than 1150 laboratories gave total CVs averages of $12 \%$ for Friedewald LDL-C ${ }^{18}$. This CV reflects not only the imprecision within laboratories, but also the method-to-method biases from many different assays used in TC, HDL-C and TG determinations. In our study, imprecision of Sentinel dLDL-C was better than that of the Vitros dLDL-C, and Vitros dLDL-C was not able to meet the performance criteria which has a total imprecision below $4 \%$ as recommended by the NCEP. Medically allowable error could not be estimated, because we did not determine the bias by using the reference method. Linearity performance for Sentinel dLDL-C was also better than that of the Vitros dLDL-C. Thus, we have preferred the Sentinel dLDL-C assay method at the following part of the study.

An important indicator for the reliability of a LDL-C assay method is the correct classification of patients by the NCEP medical decision points for LDL-C. Previous studies supported the idea that direct LDL-C assay methods better classify individuals into NCEP cutpoints in comparison to the Friedewald calculation. In the present study, while hyperlipidemic group had the highest sdLDL-C concentration among the four groups, normolipidemic group had the lowest sdLDL-C level. In Table 2, groups were classified according to the Friedewald LDL-C and TG concentrations that were determined by NCEP. Although the lowest level of Friedewald LDL-C had been prospected in normolipidemics, it was observed in the hypertriglyceridemic group due to the effect of high TG level. This meant that TG concentration appears to affect the classification of individuals' NCEP medical decision points. This study demonstrates the misclassification of groups, although groups were created based on the Friedewald LDL-C. The sdLDL$\mathrm{C}$ values were concordant with the classification. In the light of these results, we considered that sdLDL$\mathrm{C}$ measurement could be more useful to evaluate the patients with the risk of hypercholesterolemia.

There were some weak points of our study. Although the accepted reference method was $\beta$-quantification, we did not determine the LDL-C values using $\beta$-quantification to compare the results with those obtained by the use of other LDL-C assay methods. In addition the sample size of our study groups was small.

\section{Conclusion}

Replacement of Friedewald formula with direct LDL-C assay methods is under debate. Measurement of accurate LDL-C levels is not possible due to the limitations of the Friedewald formula and lack of the standardized direct methods. Therefore, standardization of direct LDL-C assay methods in larger population studies and comparison of different direct methods with $\beta$-quantitative measurement are necessary. The use of analytical systems that was certified by NCEP could be more helpful to solve this problem. Sentinel direct LDL-C seems to be more useful in comparison to Vitros LDL-C for this purpose. Serum LDL-C concentrations obtained by using direct methods were significantly higher in 
comparison to those calculated by Friedewald formula. Although the mean LDL-C level difference was small, it may be clinically important when NCEP risk categories are used to assess the need for drug intervention in a particular individual. Therefore, the preference of the direct LDL-C or sdLDL-C could be more suitable for the evaluation of the patients with hyperlipidemia.

\section{Conflict of interest}

There is no conflict of interest in this paper.

\section{References}

1. Kingsburry KJ, Bondy G. Understanding the essentials of lipid metabolism. Prog Cardiovasc Nurs 2003; 18: 13-8.

2. MRC/BHF Heart Protection Study of cholesterol lowering with simvastatin in 20,536 high-risk individuals: a randomised placebo-controlled trial. Lancet 2002; 360: 7-22.

3. Executive summary of the third report of the National Cholesterol Education Program (NCEP) expert panel on detection, evaluation and treatment of high blood cholesterol in adults (Adult Treatment Panel III). JAMA 2001; 285: 2486-97.

4. Kannel WB. Range of serum cholesterol values in the population developing coronary artery disease. Am J Cardiol 1995; 76: 69C-77C.

5. Christenson RH. National Academy of Clinical Biochemistry Laboratory Medicine Practice Guidelines for utilization of biochemical markers in acute coronary syndromes and heart failure. Clin Chem 2007; 53: 545-6.

6. St-Pierre AC, Ruel IL, Cantin B, et al. Comparison of various electrophoretic characteristics of LDL particles and their relationship to the risk of ischemic heart disease. Circulation 2001; 104: 2295-9.

7. Hirano T, Ito Y, Saegusa H, et al. A novel and simple method for quantification of small, dense LDL. J Lipid Res 2003; 44: 2193-201.

8. Koba S, Hirano T, Yoshino G, et al. Remarkably high prevalence of small dense low-density lipoprotein in Japanese men with coronary artery disease, irrespective of the presence of diabetes. Atherosclerosis 2002; 160: 249-56.

9. Mohan V, Deepa R, Velmurugan K, et al. Association of small dense LDL with coronary artery disease and diabetes in urban Asian Indians- the Chennai Urban Rural Epidemiology Study (CURES-8). J Assoc Physcians India 2005; 53: 95-100.

10. Packard CJ. Triacylglycerol-rich lipoproteins and the generation of small, dense low-density lipoprotein. Biochem Soc Trans 2003; 31: 1066-9.

11. Friedewald WT, Levy RI, Frederickson DS. Estimation of the concentration of low-density lipoprotein cholesterol in plasma, without use of the preparative ultracentrifuge. Clin Chem 1972; 18: 499-502.
12. Esteban-Salan M, Aguilar-Doreste JA, Arranz-Pena ML, et al. Multicentric evaluation of the homogeneous LDLcholesterol Plus assay: comparison with beta-quantification and Friedewald formula. Clin Biochem 2008; 41: 1402-9.

13. Ran Jun K, Park HI, Chun S, et al. Effects of total cholesterol and triglyceride on the percentage difference between the low-density lipoprotein cholesterol concentration measured directly and calculated using the Friedewald formula. Clin Chem Lab Med 2008; 46: 371-5.

14. Charuruks N, Milintagas A. Evaluation of calculated lowdensity lipoprotein against a direct assay. J Med Assoc Thai 2005; 88: 274-9.

15. Tighe DA, Ockene IS, Reed G, et al. Calculated low density lipoprotein cholesterol levels frequently underestimate directly measured low density lipoprotein cholesterol determinations in patients with serum triglyceride levels $<$ or $=4.52 \mathrm{mmol} / \mathrm{l}$ : an analysis comparing the LipiDirect magnetic LDL assay with the Friedewald calculation. Clin Chim Acta 2006; 365: 236-42.

16. NCCLS. $2^{\text {nd }}$ ed. Evaluation of precision performance of quantitative measurement methods; Approved Guideline. NCCLS document EP5-A2. Wayne, PA USA: NCCLS; 2004.

17. Tholen DW. $1^{\text {st }}$ ed. Evaluation of the Linearity of Quantitative Measurement Procedures: A Statistical Approach; Approved Guideline, EP06-A. Clinical and Laboratory Standards Institute; 2003.

18. Nauck M, Warnick GR, Rifai N. Methods for measurement of LDL-cholesterol: a critical assessment of direct measurement by homogeneous assays versus calculation. Clin Chem 2002; 48: 236-54.

19. Nauck M, Graziani MS, Bruton D, et al. Analytical and clinical performance of a detergent-based homogeneous LDLcholesterol assay: a multicenter evaluation. Clin Chem 2000; 46: 506-14.

20. Bachorik PS, Ross JW. National Cholesterol Education Program recommendations for measurement of lowdensity lipoprotein cholesterol: executive summary. The National Cholesterol Education Program Working Group on Lipoprotein Measurement. Clin Chem 1995; 44: 1414-20.

21. Cordova CM, Schneider CR, Juttel LD, et al. Comparison of LDL-cholesterol direct measurement with the estimate using the Friedewald formula in a sample of 10664 patients. Arquivos Brasilieros de Cardiologia 2004; 83: 482-7. 